\title{
Protective effect of placental mesenchymal stem cells on histological changes of pancreas experimentally induced by alloxane in mice
}

\author{
H.Kh. Ismail ${ }^{*}$, R.A. Al-Sabawy ${ }^{2}$ and H.J. Jumaa ${ }^{2}$ \\ ${ }^{1}$ Department of Pathology and Poultry Disease, College of Veterinary Medicine, ${ }^{2}$ Department of Biology, College of Science, \\ University of Mosul, Mosul, Iraq, *Email: hana_khismail@yahoo.com
}

(Received June 13, 2018; Accepted September 8, 2018)

\begin{abstract}
In an attempt to find a treatment for diabetes by Placental mesenchymal stem cells, we induced diabetes in albino mice by injected them with the diabetic agent Alloxan intra peritoneal cavity dose $70 \mathrm{mg} / \mathrm{kg}$ of body weight for the group 1 and 2 , then injection of the diabetic mice with Placental mesenchymal stem cells in the peritoneal cavity for the group 2 then the glucose levels in the blood of these mice were measured by using a GLUCOTREND 2, while group 3 was control injected with normal saline only. Pancreas tissue where tested by studying histopathological effect of Alloxan, the endocrine pancreas histologically showed decreased in the size and number of Langerhans islets with vacuolar degeneration and necrosis of almost all cells in the atrophied islets. Also, there was congestion of blood vessels in the interlobular space and there was distortion of exocrine pancreas. There was vacuolar degeneration and necrosis of the epithelial cells of the acini, also there was atrophy of acini which lead to edema and dilatation of interacini space. Moreover, there was thickening in the wall of blood vessels, and there was thrombus in some blood vessels. In addition to the infiltration of inflammatory cells in the interlobular septa. Compared with the section of pancreas of control group showed the normal structure of islets notice the normal cells shape surrounding by exocrine pancreas. Then the pancreas studied after injection of Placental mesenchymal stem cells, while there was regeneration of islets and acini which seem to be normal comparing with control group, there was improvement of normal histological appearance of mice treated with alloxan and then injected with placental mesenchymal stem cells. The results of the diabetic mice which treated with placental mesenchymal stem cells demonstrated present of significant differences $(\mathrm{P} \leq 0.05)$. Our conclusion of this study revealed that placental mesenchymal stem cells have a protective role against the histological changes of pancreas induced by alloxan.
\end{abstract}

Keyword: Placental mesenchymal stem cells, Diabetes mellitus, Pathological changes, Pancreas Available online at http://www.vetmedmosul.com, (C) 2020, College of Veterinary Medicine, University of Mosul. This is an open access article under the CC BY 4.0 license (http://creativecommons.org/licenses/by/4.0/).

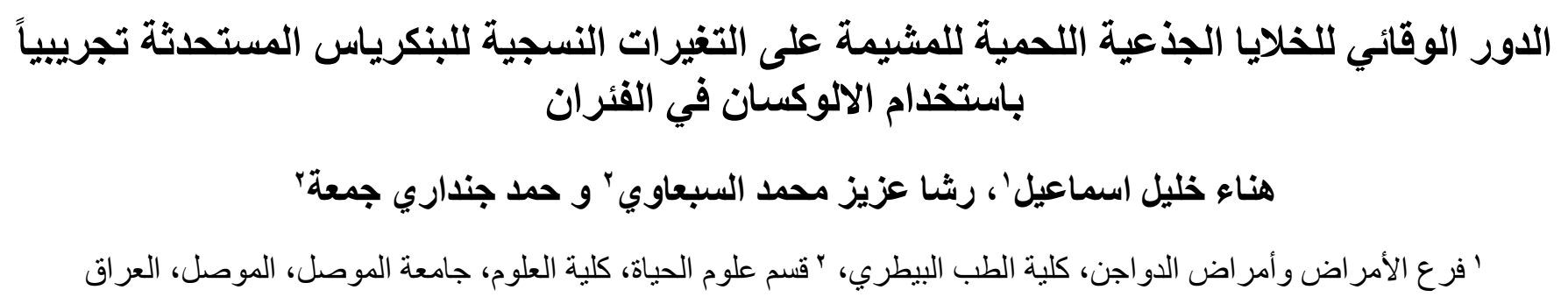

اهتمت الدر اسة الحالية حول استخدام الخلايا الجذعية اللحمية للمشيمة في علاج داء السكري المستحدث تجريبياً في الفئران المهقاء



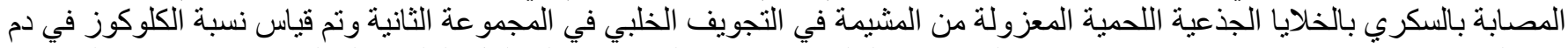
هذه الفئر ان باستخدام Glucotrend2 بينما حقتت المجموعة الثالثة (مجموعة السيطرة) بالمحلول الملحي الفسلجي. تمت دراسة التغيرات 


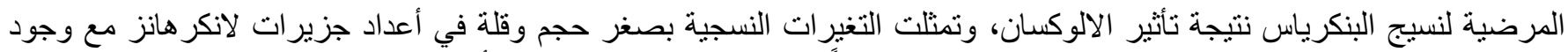



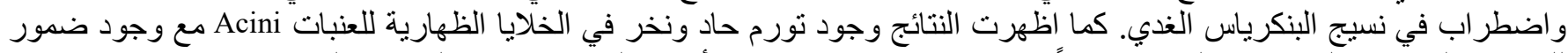

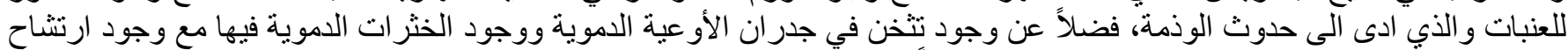

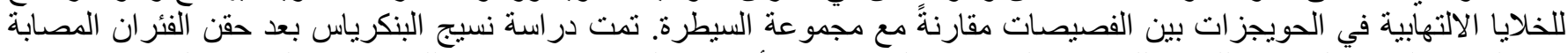

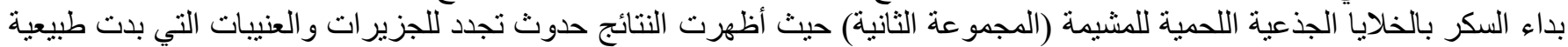

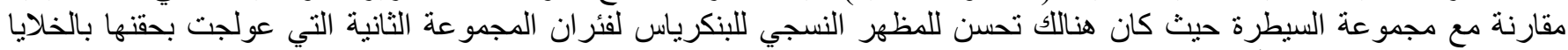



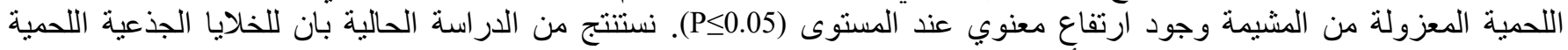
للمثيمة دور وقائي للحد من التغيرات التي أحدثها حقن الالوكسان في البنكرياس.

\section{Introduction}

For the past few years, in an attempt to find new sources of cells that may be used in cell therapy numerous researchers have highlighted the particular properties of mesenchymal stem cells (1-4). Several studies have shown the superior role of stem cells in regenerative medicine and tissue engineering because their administration, following the isolation and in vitro culture leads to the cell's engraftment in certain tissues and the release of antiinflammatory cytokines (5). This study focuses on placental mesenchymal stem cells (PMSCs) in an attempt to differentiate them in vivo into islets of Langerhans in order to treat the diabetes mellitus. The placenta is one of the most important sources of stem cells, and has been studied extensively over the past period. The placenta fulfills two main desiderata of cell therapy: obtaining high number of cells and use of non-invasive methods for their harvesting $(6,7)$.

\section{Material and methods}

\section{Animals used in the experiment}

In this study we used albino mice of the balb /c strain, the mice were in good health, they were 2-3 months of age, weighing between 25-30 gm of both sex male and female. The animal was kept in a room at temperature between $(20-25){ }^{\circ} \mathrm{C}, 12$ hour light and 12 hour dark.

\section{The drug used}

In this study Alloxan used as a diabetogenic chemical, diabetes was induced by injecting the mice with $70 \mathrm{mg} / \mathrm{kg}$ of alloxan (intra peritoneal) after fasting the animals for 24 hours (8). While glucose solution in the drinking water of diabetic condition was confirmed 24 hours. After alloxan injection, not all the mice were diabetic, they were diabetic after 72 hours (9).

\section{Measurement of glucose levels in animals}

We regarded the mice which have more than 300 $\mathrm{mg} / \mathrm{ml}$ glucose level, these mice appear tired and have polyuria. In this study we used the Glucotrend 2 instrument (UK) to measure the blood taken from the tail vein of the mice then we measure the level of glucose in every 3 day in order to check the differences in the results.

\section{Experimental design}

The experiment recommended 30 mice, 20 of these mice were injected with alloxan so all of them were diabetic and 10 mice considered as a control, they were given normal saline. Group 1: Ten mice injected with alloxan. Group 2: Ten mice injected with alloxan and then injected with placental mesenchymal stem cell suspensions. Group 3: Ten mice which considered as control, injected with normal saline only.

The blood sugar was measured before inducing diabetes to record the value, then we measured the value after 3 days from injected the mice with alloxan were recorded and after injecting the mice with cells we measured the value were recorded every 3 days, and record the results. After 21 days the animals were scarified to examine in the pancreas grossly and to study the histopathological changes.

\section{Preparation of alloxan solution}

A dose of $70 \mathrm{mg} / \mathrm{kg}$ was recommended (9), then the dose was prepared, depending on the weight and number of mice in the experiment, where $35 \mathrm{mg}$ of alloxan was freshly dissolved with $20 \mathrm{ml}$ of normal saline injected to mice IP, since $1 \mathrm{ml}$ of the solution can be given for each mouse, if diabetes doesn't occur, another dose is given.

\section{Injected placental mesenchymal stem cell to the diabetic mice}

After dissecting the animal chosen for extraction of msenchymal stem cells of its placenta the extract 
PMSCs were injected directly into the peritoneal cavity at dose $1.0 \times 10^{6}$ cells $/ 100 \mu \mathrm{L}$ phosphate-buffer saline (PBS) per mouse to diabetic animals (group 2), then the measure of blood sugar were every three days on a regular basis (10).

\section{Histological technique of light microscope}

Specimens of pancreas (of the diabetic mice and diabetic mice which injected with PMSCs) were kept in $10 \%$ neutral buffer formalin (11). The slides were prepared from pancreas according to (12). The specimens were dehydrated by series of ethanol alcohol, cleared in xylene then impregnated and embedded in paraffin wax (melting point $60^{\circ} \mathrm{C}$ in an oven for 4-6 hours. Then the specimens were blocked in paraffin wax serial transverse section of 4 microns thickness were cut by using rotary microtome. The section then floated in water bath at $37-40^{\circ} \mathrm{C}$ and mounted on a slide, then passed through hematoxylin and eosin staining method (12).

\section{Placental mesenchymal stem cells isolation}

Isolation of (PMSCs) is done according to methods used by $(13,14)$.

\section{Scanning of electron microscope examination}

The substrate was prepared by dissolving $1 \mathrm{gm}$ of gelatin in $100 \mathrm{~mL}$ of deionized distilled water and sterilized by autoclave, use this solution as the basic substrate grow on the placental stem cells, as it has been taking $0.5 \mathrm{ml}$ of a sterile prepare solution of gelatin and doused in every hole of the tissue culture plate 4-well on pieces of a sterile cover glass slide therein and left to dry inside the hood. These prepared plates were used for the cultivation of cells that later used for scanning electron microscopic examination $(15,16)$.

\section{Results}

\section{Placental Mesenchymal Stem Cells (PMSCs)}

Where the isolation of PMSCs was done at (14-16) days from pregnant mice and cultivated the cell suspension in the DMEM high -glucose media with the supplements and the suspension containing RBC, WBC and two types of the stem cells: Hematopoietic Stem Cells (HSCs) which decrease in numbers gradually and Mesenchymal Stem Cells (MSCs), in this stage we observed all types of cells took round shape as in (Figure 1). After (4 - 5) days we notice some cells began to adhere on the bottom of the tissue culture flask and beginning to take spindle shape which represent PMSCs while other stay plotting in the tissue culture flask represent (HSCs) (Figure 2). After two weeks of cultivation we observed confluence and forming monolayer as a result of attachment placental mesenchymal stem cells which have spindle shape-like fibroblastoide morphology (Figure 3).

We obtained pure culture of PMSCs after two weeks only of initial cultivation by changing the media for maintenance of the cells and discard the hematopoietic cells which were not attachment while PMSCs staying because of ability to adherent to the plastic of tissue culture flask. The most important characteristic in vitro features of PMSCs are their ability to aggregate and form colonies of fibroblast-like cells appeared in culture because of division activity when initial culture began to form this colonies at 4-5 days which expanded and gradually grew to form large individual colonies and display fibroblast-like morphology with long and short processes, also the PMSCs showed the ability to stain with H\&E stain (Figure 4).

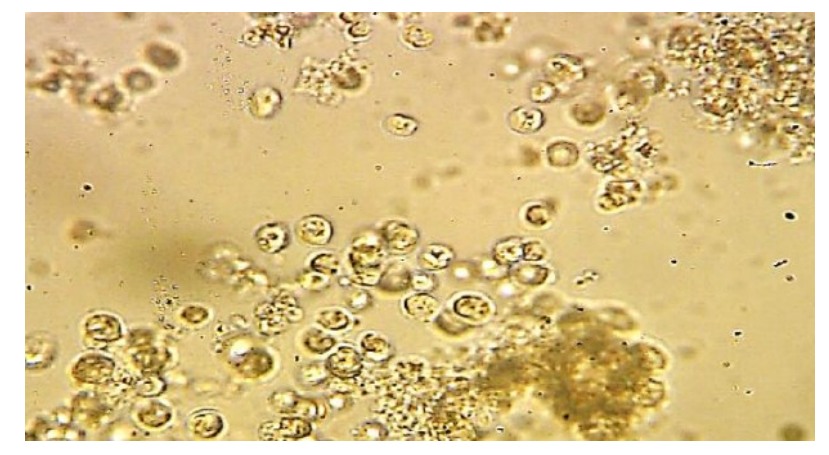

Figure 1: The Placental derived cells suspension cultured in DMEM $+10 \%$ FCS after one hour of culture under inverted microscope (200X).

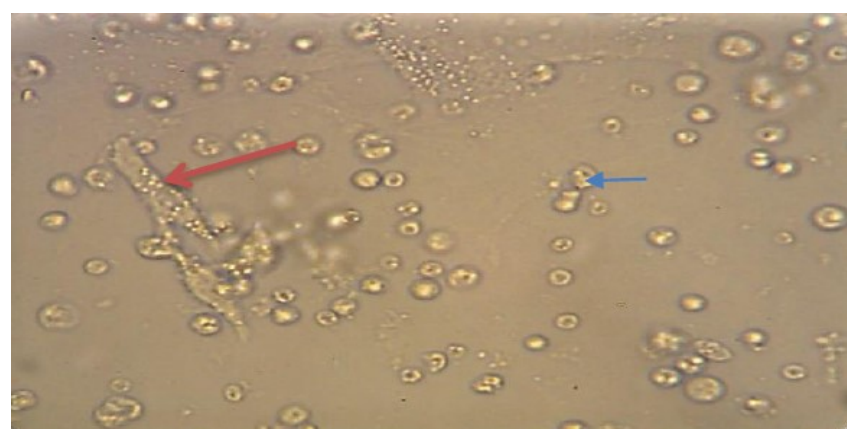

Figure 2: Placental derived cells after 4 days ( $\longrightarrow$ ) attachment of PMSCs and beginning to take spindle shape, were ( $\longrightarrow$ ) HSCs stay plotting (round shape) in the flask of culture under inverted microscope (200X).

\section{Determination the cells viability}

Testing and measuring the viability of the PMSc showed that the viability of the cells was $94.5 \%$ according to these equivalent: $\%$ viable cells $=[1.00-(4 \div 73)] \times 100$. Viable cells $=94.5 \%$ 


\section{Harvesting PMSc and determination their number}

PMSCs have high ability to proliferation and forming colonies, whereas the number of cells in harvesting cells from the initial culture after 21 days of cultivation was $14.6 \times 10^{4}$ and after culturing the cells in new tissue culture flasks, after 4-5 days we harvest the cells again which showing that the number increase to $23.9 \times 10^{4}$.



Figure 3: PMSCs forming monolayer after 2 weeks of cultivation under inverted microscope. (A) Under phase contrast (200X), (B) Under inverted microscope (400X).

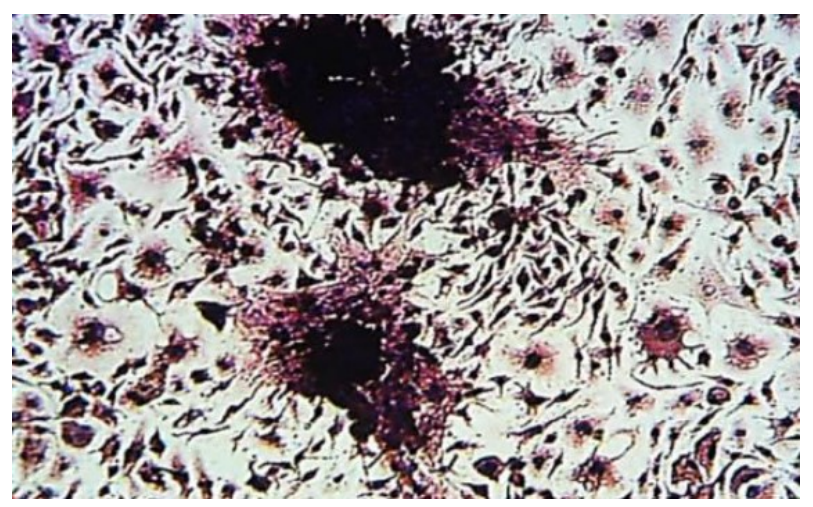

Figure 4: The ability of PMSCs to aggregate and form colonies of colony forming unit-fibroblast appeared under the inverted microscope (100x).

\section{Alkaline Phosphatase Activity (ALP)}

The PMSCs in the $2^{\text {nd }}$ and $4^{\text {th }}$ passage was stained for ALP activity, and this surface marker served as biochemical marker for dedifferentiation stem cells, so the cells have taken dark red- brown color as in (Figure 5).

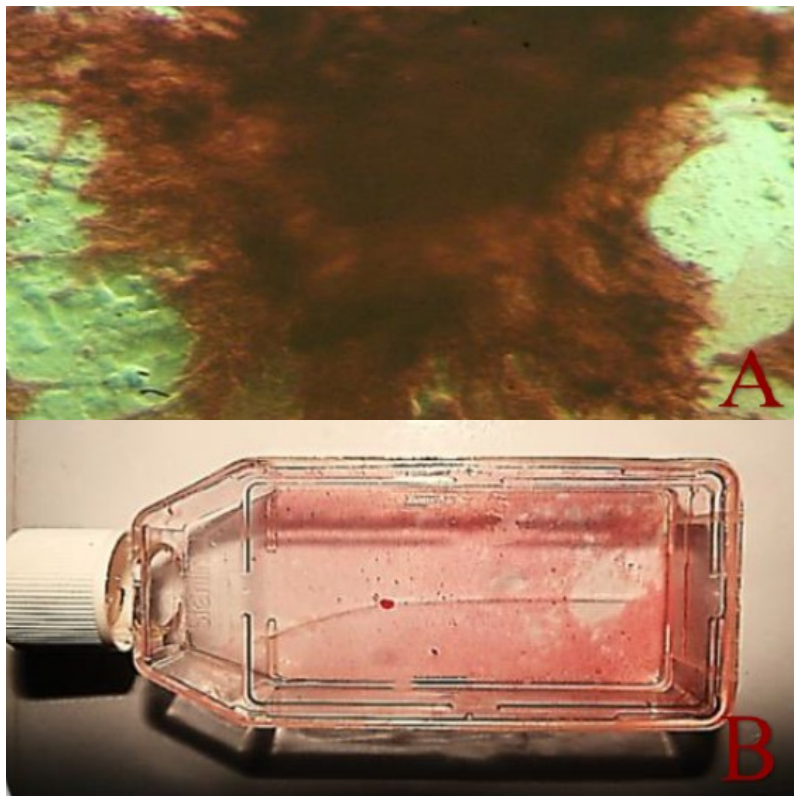

Figure 5: The alkaline phosphatase activity (dark redbrown) which represent the + ve result. (A) Under phase contrast microscope (200X). (B) The flask of alkaline phosphatase test.

\section{Electron microscope study}

In this study, we use the scanning electron microscope to observe the phenotypic characteristic of PMSc isolated from the placenta, where results showed the active and effective division of stem cell in its spherical shape as well as have been observed attachment of stem cells and the formation of protoplasmic extensions and observed filipodia which help the cells on the surface of the coverslips, also observed the lamilapoidia which represented of the surface receptors of cells and signals between the cells, we also observed the distinctive spindle shape of the mesenchymal stem cells as in (Figures 6-8).

\section{Histopathological changes in pancreas occur by Alloxan}

Alloxan induced diabetic mice, the endocrine pancreas histologically showed decreased in the size and number of Langerhans islets with vacuolar degeneration and necrosis of almost all cell in the atrophied islets as compared with control group (Figure 9). Also, there was congestion of blood vessels in the interlobular space (Figure 10), while other specimens showed that there was distortion of exocrine pancreas. There was degeneration (acute swelling) and necrosis of the epithelial cells of the acini. Also, there was atrophy of acini which lead to oedema and dilatation of inter acini space (Figure 11). 
Moreover, there was thickening in the wall of blood vessels (Figure 12), and there was thrombus in other blood vessels, we saw that there was infiltration of inflammatory cell in the inter lobular septa (Figure 13). Compared with the section of pancreas of control group showed the normal structure of islet notice the normal cells shape surrounding by exocrine pancreas.

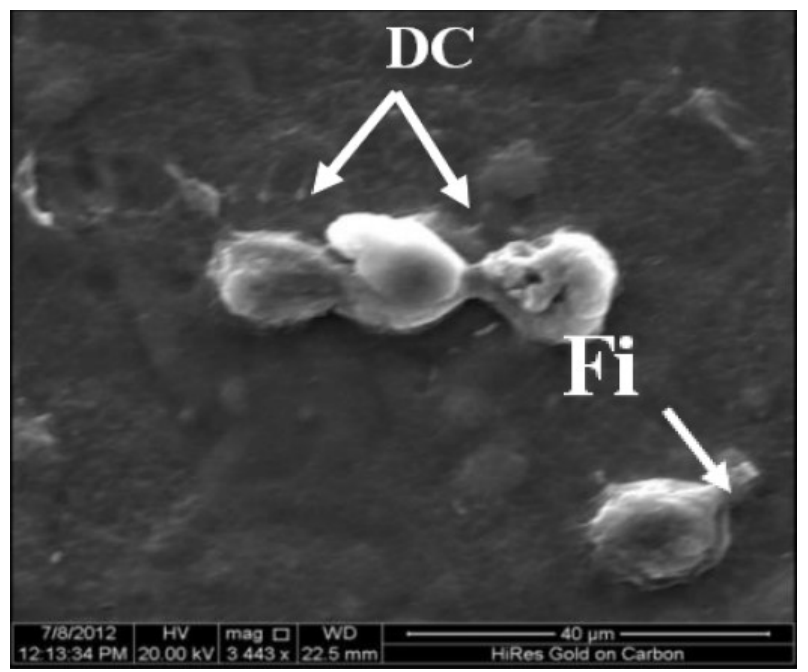

Figure 6: The scanning electron microscope shows the Filipodia (Fi) of the mesenchymal cells which is protoplasm prolong expended from cell surface helping to connect the cells with each other's, and the division cells (DC) are clear here (3443 X).

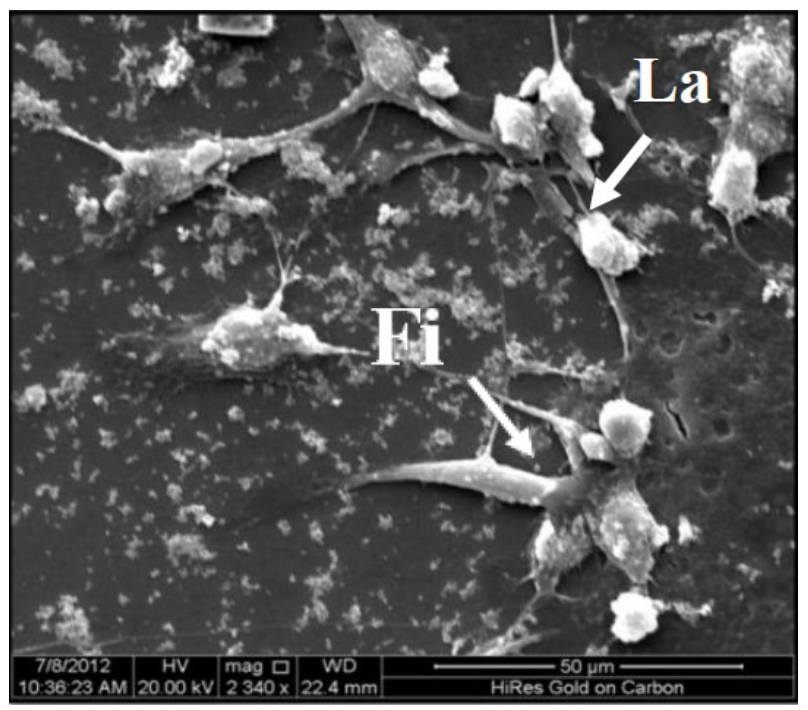

Figure 7: The scanning electron microscope shows the attachment of growing cells by the Filopodia. The Lamellipodia of the cells which represented the surface receptors (2340 X). (La) Lamellipodia, (Fi) Filopodia cell.

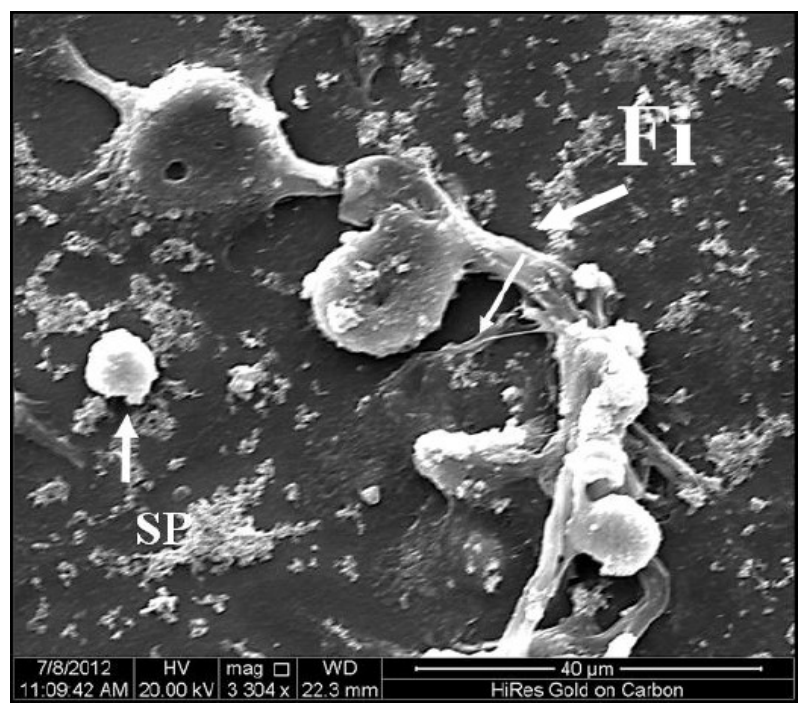

Figure 8: The scanning electron microscope shows the attachment of PMSCs by each other's by the Filopodia (3304 X). (Fi) Filopodia, (SP) Spherical cell.

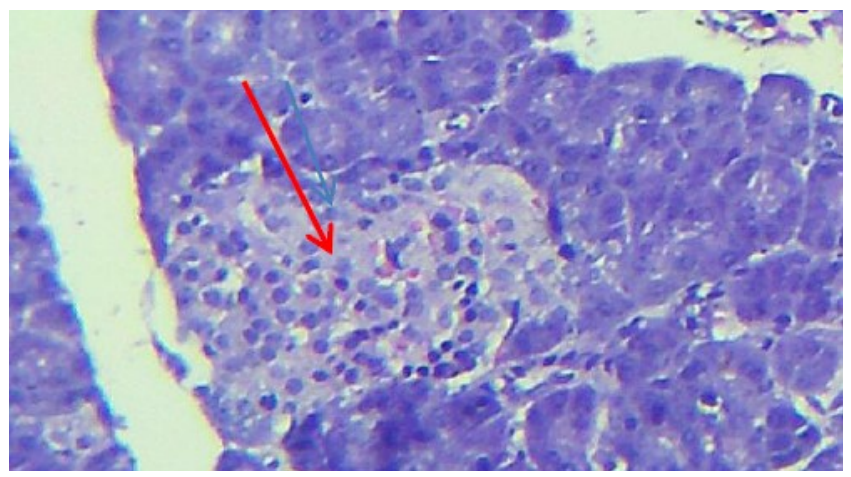

Figure 9: Section of pancreas of control group showed the normal structure of islet notice the normal cells shape surrounding by exocrine pancreas ( $\longrightarrow$ ). H\&E (420 X).

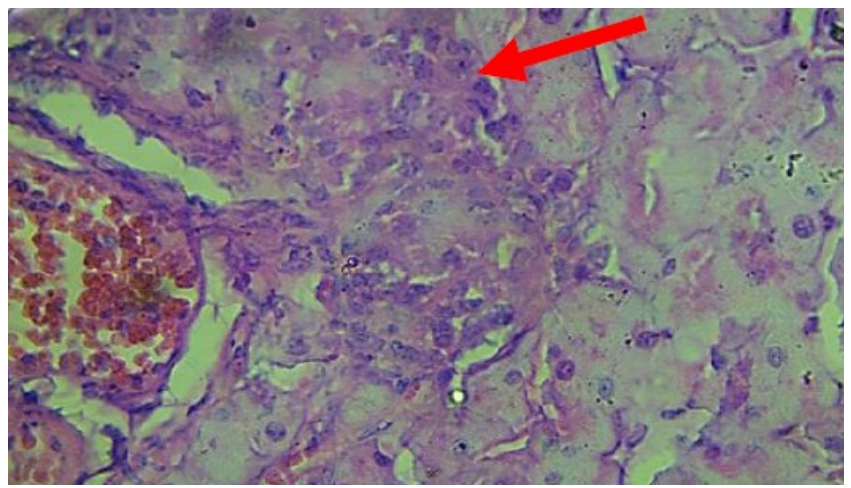

Figure 10: Section of mice pancreas of alloxan diabetic mice showed necrosis of islet cells ( $\longrightarrow$ ). H\&E (420X). 


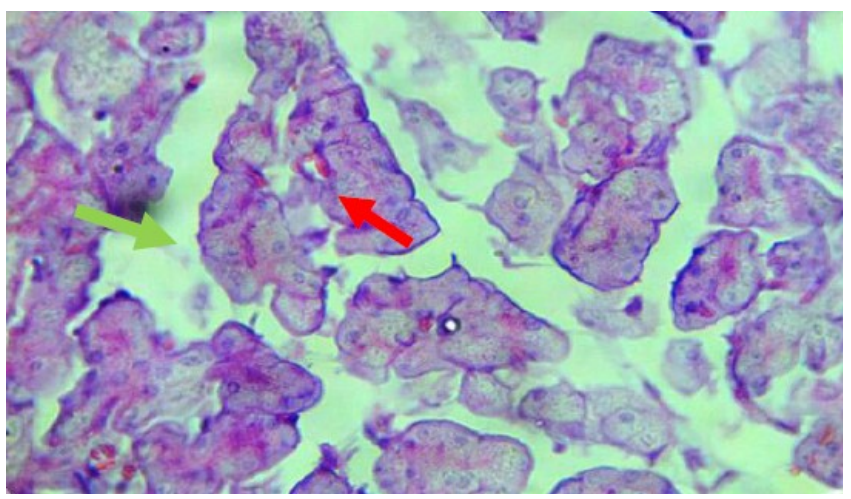

Figure 11: Section of pancreas showed distortion of exocrine pancreas, notice the degeneration and necrosis of acinar cells $(\longrightarrow)$ and there is edema $(\longrightarrow)$. H\&E (420X).



Figure 12: Section of pancreas showed the thrombus of the blood vessel. H\&E (420X).

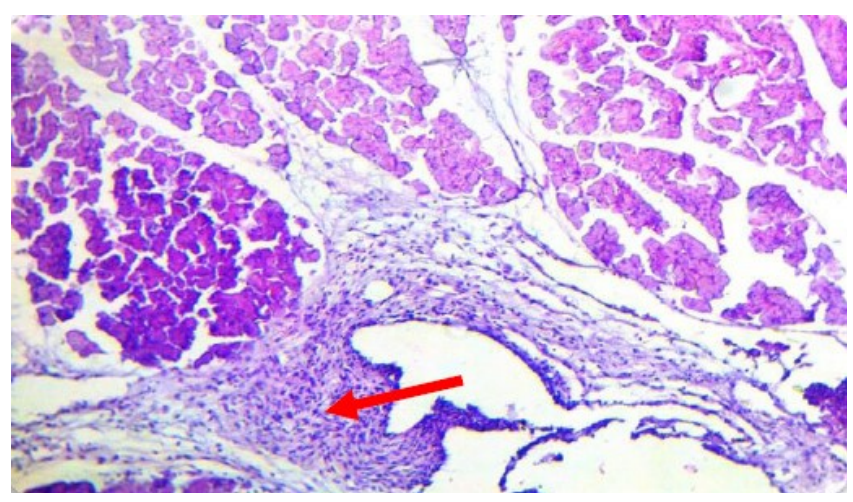

Figure 13: Section of pancreas showed inflammatory cells in the inter lobular septa. H\&E (420X).

\section{Treatment of Diabetes Mellitus in Mice by mesenchymal stem cells}

In this experiment the diabetic mice were grafted PMSCs via tail vein to treat the diabetic mice. There were two groups of mice: diabetic mice were injected with PBS, and diabetic mice were injected with PMSCs via tail vein. While there was regeneration of islets and acini which seems to be normal compared with the control group (Figure 14). There was improvement of the histological appearance of pancreas of mice treated with alloxan and then injected with placenta mesenchymal stem cells, otherwise there was fibrous exudate with edema within the interlobular septa (Figure 15).



Figure 14: Section of pancreas shows stem cells treated mice pancreas showed the improvement of the exocrine $(\longrightarrow)$ and endocrine of the pancreas $(\longrightarrow)$. H\&E (420X).

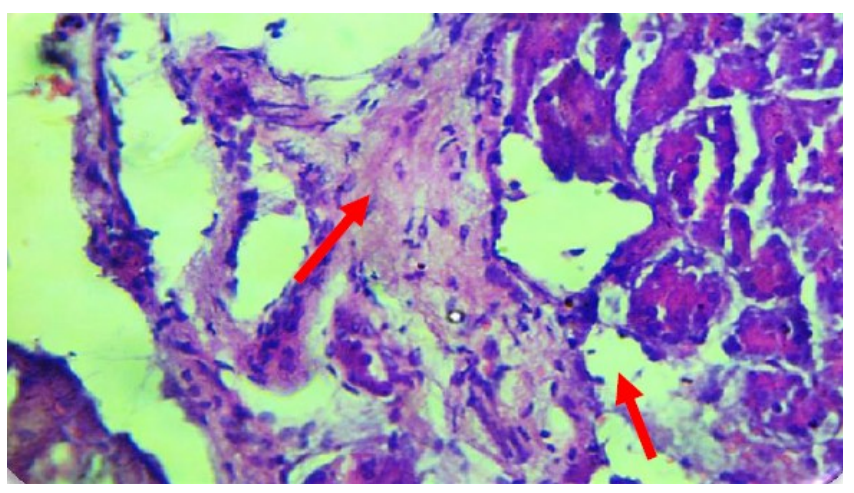

Figure 15: Section of pancreas shows mesenchymal stem cells treated mice pancreas showed fibrous exudate with edema in the interlobular septa, ( $\longrightarrow$ ). H\&E (420 X).

\section{Measurement of glucose levels in animals}

After inducing diabetes mellitus in mice we injected them with PMSCs as an attempt to treat them from diabetic mellitus so from recording the levels of sugar in the blood of mice which injected with the cells we observed a decrease in the blood sugar level in diabetic mice injected with the cells compared with control (diabetic mice which don't injected with cells) after that we dissected the mice 
and took the pancreas and liver for histopathological study, to study the effects of Alloxan and the treatment with the PMSCs on these tissues.

Table 1: Explain change of the level blood sugar

\begin{tabular}{lll}
\hline Days & Blood sugar & \\
\hline Before & $111.89 \pm 06.36$ & $\mathrm{a}$ \\
After & $367.67 \pm 14.30$ & $\mathrm{~b}$ \\
3 D & $273.00 \pm 13.08$ & $\mathrm{c}$ \\
6 D & $263.56 \pm 10.56$ & $\mathrm{c}$ \\
9 D & $195.78 \pm 18.89$ & $\mathrm{~d}$ \\
$12 \mathrm{D}$ & $175.89 \pm 15.22$ & $\mathrm{~d}$ \\
$15 \mathrm{D}$ & $166.89 \pm 17.63$ & $\mathrm{~d}$ \\
$18 \mathrm{D}$ & $192.00 \pm 26.67$ & $\mathrm{~d}$ \\
21 D & $188.89 \pm 21.78$ & $\mathrm{~d}$ \\
\hline
\end{tabular}

The same letters mean non -significant differences, the different letters mean significant differences, ANOVA $\mathrm{P}<0.05$.

\section{Discussion}

\section{Induction of Diabetes mellitus}

In this study we induced diabetes mellitus by alloxan an diabetic agent by injecting the mice with $70 \mathrm{mg} / \mathrm{kg}$ body weight and all the mice were found to be diabetic after 72 hours. this result is similar to that recorded by $(9,17)$ who use the same diabetic agent other authors use another diabetic agent Streptozotocin and obtained the same result by Phuc et al. (18) and we can detect induce the diabetes in the mice by measuring the blood sugar level by using strips.

One of the aims of this study to improve the possibility of treatment diabetes mellitus by using new therapy PMSSc instead of insulin and others treatments and by taken the measurement of the blood sugar of these diabetic animals after injected with stem cells and when we observed a marked decreased in blood sugar level we dissect the animals, and the histological study improve the recovery of the pancreatic tissue.

These results are agreement with that obtained by Chen et al and Lumelsky et al. authors $(19,20)$ when they recorded 3 methods to treatment of diabetic mice by injected Allogenic bone marrow and Xenograft of MSCs derived from umbilical cord blood, and when the treated diabetic by grafted insulin Producing cells IPCS and found that the insulin producing cells derived from MSCs had the best effect on recovering the insulin and blood sugar levels in diabetic mouse model. While Hori et al. (21) use Streptozotocin injected intravenously from caudal veins and glucose levels were tested one week later with Roche AccuChek glucose tester. After stable hyperglycaemia level was achieved 3 animals were subcutaneously injected with $5 \times 10^{6}$ differentiated cells the reaming 1 didn't receive any cells. One week after cell injection, animal glucose level was recorded. He found that MSCs and successfully differentiated in to pancreatic islet $\beta$-like cells. These cells were morphologically similar to pancreatic islet cells. More importantly, they could also transcript, translate and excrete insulin. Cells were injected subcutaneously in to NOD rat model, although lack of statically data, these MSCs derived cells could regulate NOD blood glucose level. Nestin was regarded as a marker of precursors of pancreatic islet cells $(22,23)$

\section{Treatment the diabetic Mice with PMSCs}

After induced diabetes mellitus in mice we injected them with PMSCs as attempt to treat them from diabetic mellitus so from recording the levels of sugar in the blood of mice which injected with the cells we observed decrease the levels of sugar in diabetic mice which injected with the cells compared with control (diabetic mice which don't injected with cells) after that we dissected the mice and taken the pancreas for histopathological study, to study the effects of Alloxan and the treatment with the PMSCs on these tissues. To date (24) brought the evidence that umbilical cord blood cells, after culture in medium supplemented with fetal calf serum (in the absence of specific cytokines or growth factors, (show a panel of markers consistent with the characters of epithelial cells expressing genes considered essential in the differentiation steps towards pancreatic endocrine tissue (Isl-1, PDX-1 , Pax-4 and Ngn3).

\section{The histopathological effect of alloxan in the animal's organs}

Diabetes mellitus is the most common endocrine disorders in addition to the primary effects of diabetes, this disease is accompanied by increased risk factors such as hyperglycemia, hypertention, dyslipidemia, decreased fibrinolytic activity, seer atherosclerosis and increased platelet aggregation $(25,26)$.

In agreement of our results, (27) found when he induce diabetes in rats and try to treat it with extract of plants found that Alloxan showing that necrotic changes of the islets of pancreatic, nuclear changes such as pyknosis, karyorrhexis, karyolysis, disappearance of nucleus and in some place residues of the destroyed cells were visible. Relative reduction in the size and number of the islets especially those around the central vessel together with severe reduction in the $\beta$-cells were demonstrated in these animals. Histopathological study of the treated diabetic rats that received garlic and Capparis spinosa extracts did not show a significant difference with the untreated diabetic rats. The cellular integrity and architecture of pancreases were intact in the control group. So, the histological change of pancreas in diabetic animals occur as a result of the pathogenesis of diabetes mellitus. Histopathological 
changes of pancreas of diabetes mellitus, characterized by reduced of $\beta$ cells mass result from either an impaired proliferative capability or an elevated rate of cell death (28).

\section{References}

1. Pittenger M, Mackay A, Beck S, Jaiswal R., Douglas R., Mosca J, Moorman M, Simonetti D, Craig S, Marshak, D.. Multilineage Potential of Adult Human Mesenchymal Stem Cells. science, 1999; 71(284):143-147. https://doi.org/10.1126/science.284.5411.143

2. Rochefort G, Delorme B, Lopez A, Hérault O, Bonnet P, Charbord P, Eder V, Domenech J. Multipotential Mesenchymal Stem Cells Are Mobilized Into Peripheral Blood By Hypoxia, Stem Cells, 2006; 24(10):2202-2208. https://doi.org/10.1634/stemcells.2006-0164.

3. Buhring H, Acher W, Hart M, Rolauffs B, Badke A, Klein G. Regeneration of cartilage and bone by defined subsets of mesenchymal stromal cells-potential and pitfall. Cell. 2007; 47 (12):2020-2026. https://doi.org/10.1016/j.addr.2010.12.004

4. Chamberlain G, Fox J, Ashton B, Middleton J. Mesenchymal stem cells : their phenotype, differentiation capacity, immunological features and potential for homing. Stem cells .2007;25(11):2739-49. https://doi.org/10.1634/stemcells.2007-0197

5. Wenny R, Hart C, Corradi-Perini C. A small proportion of mesenchymal stem cells strongly expresses functionally active CXCR4 receptor capable of promoting migration to bone marrow .Blood. 2004;104(9):2643-2645. https://doi.org/10.1182/blood-200402-0526.

6. Miki T, Lehmann T, Cai H, Strom S. Isolation Of Multipotent Stem Cells From Placenta. Hepatology 2003;38(4):290. https://doi.org/10.1016/s0270-9139(03)80322-1

7. Matikainen T, Laine J. Placenta-an alternative source of stem cells. Toxicol Appl Pharmacol, 2005;207:544-549. https://doi.org/ 10.1016/0378-8741(88)90229-2

8. Ajabnor A, Tilmisany A. Effects of Trigonella feonum graceum on blood glucose levels in normal and Alloxan-diabetic mice. J. Ethnopharmacol., 1988; 22: 15-49.

9. Ene A, Nwankwo E, Samdi L. Alloxan-Induced Diabetes in Rats and the Effects of Black Caraway (Carum carvi L.) Oil on Their Body Weights. Journal of Pharmacology and Toxicology. 2008; 3( 2):141146. https://doi.org/10.3923/jpt.2008.141.146

10. Ezquer F, Ezquer M, Simon V, Pardo F, Yañez A, Carpio D, Conget P. Endovenous administration of bone-marrow-derived multipotent mesenchymal stromal cells prevents renal failure in diabetic mice. Biol Blood Marrow Transplant. 2009; 15(11):1354-65. https://doi.org/10.1016/j.bbmt.2009.07.022

11. Luna L. Manual of Histological Staining Methods of the Armd Forces Institute of Pathology. New york .3rd 1986; MeGraw-Hill.

12. Bancroft J, Stevens A. Theory and Practice of Histological Techniques. chuchill living stone. London 2nd.ed. 1982; 662.

13. Gekas C, Rhodes K, and Mikkola H. Isolation and Analysis of Hematopoietic Stem Cells from the Placenta. J. Vis. Exp. 2008; (16), e742, doi:10.3791/742. https://doi.org/10.3791/742
14. Rhodes K, Gekas C, Wang Y, Lux C, Francis C, Chan D, Conway S, Orkin S, Yoder M, and Mikkola H. The Emergence of Hematopoietic Stem Cells Is Initiated in the Placental Vasculature in the Absence of Circulation. Cell Stem Cell. 2008; 2:252-263. https://doi.org/10.1016/j.stem.2008.01.001

15. Pollard J, Walker J. Basic Cell Culture Protocols.2nd ed. Human Press.1997; Totowa, New Jersey .

16. Olovsson M, Nilsson BO. Structural and functional properties of trophoblast cells of mouse egg-cylinders in vitro.Anat Rec. 1993 Jun;236(2):417-24. https://doi.org/10.1002/ar.1092360217

17. AL-Badri S D. The effect of aqueous olive leave extract on streptozotocin induced diabetes mellitus in mice .Thesis 1999; ALMustansiriya University

18. Phuc P, Truc P, Thuy D, Nhung H, Chung D, Toan N, Phuc M, Ngoc P. Regeneration of Pancreatic B Cells of Type 1 Diabetic Mouse by Stem Cell Transplatation, The Third International Conference on the Development of Biomedical Engineering in Vietnam 2010, pp 163166. https://doi.org/10.1007/978-3-642-12020-6_40

19. Chen L, Jiang X, Yang L. Differentiation of rat marrow mesenchymal stem cells into pancreatic islet beta-cells . World J Gastroenterol. 2004; 10(20):3016-3020. https://doi.org/10.3748/wjg.v10.i20.3016.

20. Lumelsky N, Blondel O, Laeng P, Velasco I, Ravin R, McKay R. Differentiation of embryonic stem cells to insulin-secret-ing structures similar to pancreatic islets. Science, 2001; 292:1389-1394. https://doi.org/10.1126/science.1058866

21. Hori Y, Rulifson I, Tsai BC, Heit JJ, Cahoy JD, Kim SK . Growth inhibitors promote differentiation of insulin-produc-ing tissue from embryonic stem cells. Proc Natl Acad Sci. 2002; 99: 16105-16110. https://doi.org/10.1073/pnas.252618999

22. Pessina A. Pancreas developing markers expressed on human mononucleated umbilical cord blood cells. Biochemical and Biophysical Research Communications.2004; 323:315-322.

23. Williams G, and Pickup C. The Handbook of Diabetes.. 2004; third ed. https://doi.org/10.1016/j.bbrc.2004.08.088

24. Rajalakshmi M, Eliza J, Cecilia E, Nirmala A, Daisy F. Anti-diabetic properties of Tinospora cordifolia stem extracts on streptozotocininduced diabetic rats. African Journal of Pharmacy and Pharmacology. 2009; 3(5). 171-180 .

25. Hashemnia M, Oryan A, Hamidi A, Mohammadalipour A. Blood glucose levels and pathology of organs in alloxan-induced diabetic rats treated with hydro-ethanol extracts of Allium sativum and Capparis spinosa. African Journal of Pharmacy and Pharmacology, 2012; 6(21): 1559-1564. https://doi.org/10.5897/ajpp12.330

26. Zachary J, and McGavin M. Pathologic Basis of Veterinary Disease .4th ed. 2007; Mosby Elsevier. https://doi.org/10.1111/j.14631326.2007.00718.x

27. Maedler K. Beta cells in type 2 diabetes - a crucial contribution to pathogenesis. Diabetes, Obesity and Metabolism. 2008; 10(5): 408420.

28. Souhami R, and Moxham J. Textbook of medicine. 3rd ed.1997; Edinburgh: Churchill Livingstone. 